\title{
SELF-DEPRECATION OF HORACE'S SATIRICAL VOICE DURING THE SATURNALIA CELEBRATIONS (SATIRES 2.3 AND 2.7)
}

\author{
A Kallergi (University of Ioannina)
}

\begin{abstract}
This paper examines two of the most famous Horatian Satires $(2.3$ and 2.7), in order to shed light on the way that the poet can direct his satire not only against different types of characters (the avarice, the flatterer, the legacy-hunter), but also against himself. For this purpose, he uses the two different satirical voices of Damasippus and Davus, and he inverts the roles of slave and master, so as to eventually achieve the creation of his own complex and ambiguous persona, which displays many of the flaws criticized by the poet himself in other poems of the same collection.
\end{abstract}

Keywords: Saturnalia festivities, satirical persona, Horace, Stoicism.

\section{Introduction}

The purpose of the present article is to give prominence to the tendency of the Roman poet Horace to be self-critical. Horace addresses this satire against himself, as it becomes clear through the study of Satires 2.3 and 2.7, and more specifically his dialogue with the two other Horatian personae - Damasippus and Davus respectively — during the Saturnalia festivities. ${ }^{1}$ More specifically, the paper intends to elaborate on the aspect of self-satirizing in Horatian satire as discussed by previous scholars.

\section{Damasippus and Horace in Satires 2.3}

The principal point of focus in Satires 2.3 is the notion that human exaggeration (in a positive or negative sense) can be considered a kind of human madness. In this context, Horace is influenced by the philosophical dialogues of Plato. ${ }^{2}$

1 At this time, the relationship between slaves and their masters was temporary altered, due to the fact that they changed roles - slaves could for the time being, act as they pleased. For further details concerning Saturnalia, see Evans 1978:307-310; Bernstein 1987:450-474; cf. Sharland 2005:103-120, who elaborates on the relationship between Satires 2.3 and 2.7. She also employs Bakhtin's notions of 'dialogue' and, the Carnivalesque, to argue that the Saturnalian context in Satires 2.3 and 2.7 could be viewed as an ancient precursor of the 'Carnivalesque'.

2 See also Plaza 2006:208-211, who claims that Horace 'employs the outward shape of Socratic irony as a device to win his readers' sympathy, and indeed to make them expect, and look for, deep wisdom in his satire, without necessarily expressing that wisdom. Instead, he serves brilliant poetry, and mimetic representation of life's 
The poet introduces a new interlocutor, Damasippus, a former art dealer and connoisseur, who went bankrupt and decided to commit suicide, but was dissuaded from doing so at the last minute by the Stoic philosopher Stertinius. ${ }^{3}$ Both Damasippus and Stertinius are Horace's fictional characters and comprise secondary satirical voices, which examine the poet from a Stoic perspective, as he is a victim of his passions. In Satires 2.3, Damasippus is the main speaker, who is accusing the poet of being possessed by a form of human madness. Here Horace falls prey to the most talkative of all the doctores inepti, the garrulous Damasippus. $^{4}$

The discourse begins with Horace retiring to the countryside, seeking in vain inspiration to compose his poems. He does not manage to write many verses there, however, the use of few verses is one of the features of his satire (verses 1-

complexity, both of which are actually built into the surface'. Plaza also compares Socrates with the Horatian persona of Priapus in 1.8. Anderson 1982:13-49 deems Socrates as the ultimate example of an ironist in antiquity; Horace on the contrary is a Roman Socrates, who conceals his irony under a mask of humour typical of satiric poetry; $c f$. Sharland 2010:42-43 for further details.

3 Given the Saturnalian context, it would seem appropriate that Damasippus should be of servile origin. The clearly Greek origins of his name also strengthen this impression. According to Verboven 1997:208, $\Delta \alpha \mu \alpha \sigma i \pi \pi \eta$, the 'Horse-tamer', was an epitheton of the goddess Athena. Bacchylides denotes the region of Lydia by the same epithet. Damasippos/Damasippe was also a Greek personal name; Damasippe was the wife of the mythical Thracian king Cassandrus. Penelope's brother, a son of Icarius and the nymph Periboia, also seems to have been a Damasippos. A general of Philippus of Macedonia was also called Damasippos, as was the father of the philosopher Democritus. But many scholars have queried this, e.g. Shackleton Bailey 1982, who asserted that this Damasippus was probably Lucius Licinius Crassus Damasippus who is mentioned in a late Republican inscription. His praenomen Lucius may refer to his grandfather; $c f$. also Treggiari 1973:245-261 for further details. However, Rawson 1985:88-89, suggested that Horace's Damasippus in Satires 2.3 was rather more likely the son of the praetor Junius Damasippus, who was supported by Marius and killed by Sulla. This Damasippus was of relatively high social origins, but was debarred from entering public life; Rawson suggests he became an art dealer instead (and this is how he appears at Cicero Ad fam. 7.23; Ad Att. 12.29). I believe that Damasippus in 2.3 is not a real person, but only a persona of Horace, based on the art dealer mentioned by Cicero, in order to represent all men of high society who were interested in philosophy and arts. Likewise, Verboven 1997:216 states that 'Horace's characters did not truly reflect the historical individuals who inspired him. He was merely mockingly holding a mirror for their like and admonishing them. Horace's ideals, although shared by most of his contemporaries, hardly reflected reality. They recalled a pristine world that was easier and better to live in. In real life people preferred cash on the nail to dreams of happy poverty'.

4 See also Bond 1998:82-94 for further reading on the Stoic aspects of Horace's Satires 2.3, as well as Sharland 2009:113-131. 
5). Damasippus then begins to expound the arguments used by Sterninius in order to prove that folly is a common characteristic of many people, and for that reason Damasippus should not commit suicide. The most basic forms of human madness are avarice, self-indulgence, ambition, extravagance, sex and superstition. Avarice (which the poet has rebuked in his first book of Satires), as well as prodigality, are the most reprehensible and most serious forms of insanity (insania, verse 82):

\section{danda est ellebori multo pars maxima avaris}

To the covetous we ought to give by far the largest dose of hellebore. ${ }^{5}$

On the contrary, health and sanity are attributed to simple living based on moderation (41-167). Ambition in turn is akin to parsimony. In this case, Damasippus prefers to bolster his arguments with mythological exempla drawn from ancient literature which would be familiar to contemporary Romans. Ajax and Agamemnon serve as negative examples of ambition (ambitio, intertwined with insanity and rage respectively), while the corresponding positive exemplum is Servius Oppidius, who, on his deathbed, bound both his sons by oath to live a good and modest life (168-223). ${ }^{6}$

Oppidius (reminiscent of Ofellus in Satires 2.2) is a person unknown to the average Roman of Horace's time. ${ }^{7}$ However, the story which is narrated here by the poet takes place in Canosa, located near Apulia and Venusia, on the right bank of the river Ofanto, a place familiar to him, which is also mentioned in the first book of Satires. Therefore, this particular story is directly related to Horace's place of origin. Both Oppidius (2.3) and Ofellus (2.2) as well as the author's father (1.6), are familiar to Horace but not to his readers. They express the core ethical values of the whole collection and mainly the author's desire to highlight the importance of moderation as the ultimate principle that should rule our lives.

In other words, Oppidius is a spokesman of a world unknown to the average Roman of the poet's time, a voice expressing abiding and traditional ideas with which Horace would like to permeate the souls of his corrupt and greedy fellow citizens. Therefore, there is an excellent switch between mythological examples familiar to the average reader and the corresponding ones from Horace's birthplace which are not so well known, in order to highlight both aspects of ambition (negative and positive) and to present the latter as the most appropriate and ideal one. Even great heroes such as Ajax and Agamemnon went to extremes, while there are modest and humble people who lived wisely and with moderation

5 The translations of the Latin texts are my own. I wish to express my gratitude to Gregoria Dama (translator of English language) for her suggestions and her insightful feedback.

6 For further information concerning the characters in Satires 2.3 see Bond 1987:1-21.

7 Muecke 1993:150. 
(Oppidius). Subsequently Damasippus (224-280) mentions two other forms of folly: First, extravagance or ostentatious display of wealth:

nunc age luxuriam et Nomentanum arripe mecum / Vincet enim stultos ratio insanire nepotes

Now, come, arraign with me extravagance and Nomentanus; because reason will prove that spendthrifts are foolish and mad men (224-225)

and second, sex:

si puerilius his ratio esse evincet amare / nec quicquam differre, utrumne in pulvere, trimus / quale prius, ludas opus, an meretricis amore / sollicitus plores

Now, if reason can show that love is even more / puerile than these, that it is important not whether you play / with sand like a three year old kid, or cry with frustration / for love of a mistress (250-253).

These follies are signs of lax morals and misconduct. The speaker uses numerous examples from contemporary Roman history and introduces many inner voices of lovers who behave irrationally and allude to the corresponding heroes we find in fabula palliata and love elegy. For instance, in verses 258-271, a foolish lover who clings to the door of his beloved, debates with his faithful slave about how to react to his mistress' behaviour, who has shut him out and does not let him approach. ${ }^{8}$ The slave then gives him advice, referring to the servus callidus of fabula palliata and explains that love is an unpredictable force in the hearts of lovers. ${ }^{9}$

Horace's satirical persona so far seems less verbose and allows Damasippus to expound his arguments. ${ }^{10}$ In verse 296 , the poet asks the latter what his own

8 Horace has Damasippus even refer to the stock figure here as amator/exclusus (2.3.259260), and show how foolish he is. The poet as speaker also made fun of the exclusus amator at Satires 1.2.64-72, where Villius' 'prick' (muto) is even personified and imagined giving the foolish lover a talking-to. Likewise, at Satires 2.7.46-94, Davus gets to characterize Horace, his addressee on the occasion of the Saturnalia, as an habitual exclusus amator and thus a slave to his mistress.

$9 \quad$ In this case, Horace is directly influenced by the relevant scene found in Terence's Eunuchus between Phaedria and Parmeno (46-73). For further study concerning the intertextual dialogue between Satires 2.3 and this Terentian comedy, see Muecke 1993:160-161.

10 According to Sharland 2009:128-129, Horace seems to find this satire so boring that he makes no comment on it and remains 'silent' between lines 31 and 300. She also claims that the name of Stertinius may be connected with the Latin verb stertere (to snore), taken for granted that Stertinius's (Prof Snore's) speech is long enough to have a soporific effect on a sophisticated audience that finds all the arguments of the speaker somewhat burdensome. In other words, his long-windedness makes his listeners snore, 
form of madness is and he in turn accuses him of grandiosity (imitating Maecenas) and uncontrolled sexual passion (300-304). His greatest malady, however, is his love for writing poetry (321-322):

adde poemata nunc, hoc est, oleum adde camino / quae siquis sanus fecit, sanus facis et tu

If any man ever wrote verses while he was sane / then you are sane in writing yours.

Undoubtedly, the myth with the frogs in verses $314-320$ is an excellent choice, where the poet with exquisite satirical technique and an acute sense of humour indirectly rebukes his own as well as others' vanity. ${ }^{11}$ The little frog is rescued from the big calf, unlike the rest of his siblings, and tries to imitate the mammal's size while narrating the incident to his mother but grossly exaggerates.

Once more, as earlier in the case of Oppidius, Horace exploits a myth which is very simple and familiar to most Romans of his time, already known from Aesop, while his narrative style throughout the dialogue between the two frogs is just as simple and comprehensible. ${ }^{12}$ Therefore, the poet restructures the concept of exemplum in the context of satire, as the famous examples from the well-known mythological tradition are replaced by other less known but apprehensible ones which are familiar to the readers. ${ }^{13}$ That is to say, in this way the satire becomes explicit to all readers, and the truth it conveys is proclaimed to be universal and close to reality, without constituting a sophisticated genre of poetry. The epilogue is completed in verse 326 and is filled with intense humor, where the poet, as the lesser madman, asks his interlocutor to show sympathy and spare him:

o maior tandem parcas, insane, minori

O greater man, spare, I pray, the minor mad one.

while they are sitting in a boring lecture. Besides, Sharland suggests that Horace says nothing between lines 31 and 300, because he has become passive, as he has fallen asleep. When Horace wakes up, somewhere prior to line 300 , the satire is about to come to an end.

11 Rudd 1966:176-178 presents this myth and its different versions both in ancient Greek and Roman traditions. The comparable fables in other sources are Aesopica 376 and 376a, Babrius 28, and Phaedrus 1.24 (discussed by Rudd 1966:176ff; $c f$. Muecke 1993:165). It is also striking that Maecenas' seal displayed the image of a frog, so the connection is doubly appropriate (see Rudd 1966:297-298 n. 26). Although Damasippus is trying to make the point that Horace is getting 'too big for his boots' in his attempt to emulate his patron Maecenas and that he will presumably burst if he strains any harder, the actual inflated one in this satire is Damasippus himself and his bombastic, seemingly endless lecture (see also Sharland 2010:246-247).

12 Muecke 1993:165.

13 Schoder 1944:112-114 analyses the use of mythical exempla in all the Horatian satires. 
Consequently, the creator here disguised as Damasippus records the basic forms of human insanity (insania) and mocks the methodology and Stoic way of thinking of his time through examples which are perceptible and familiar to contemporary Romans. This is aptly put by Plaza:

At the same time, the fact that Damasippus describes writing as a form of human folly, gives a comical overtone to the poem (a feature appropriate to the genre of satire) and mocks the poet aiming at highlighting an equally basic foible of Horace's persona, his overdependence on Maecenas. ${ }^{14}$

\section{Davus and Horace in Satires 2.7}

The central theme of Satires 2.7, on the other hand, is legal and moral freedom, while at the same time the fifth Stoic paradox according to Cicero is presented:

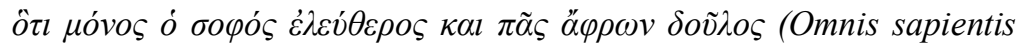
liberos esse et stultos omnis servos).

only the wise are free and the unwise slaves.

It is reminiscent of Satires 2.3, but in the present case Davus, Horace's servant, during the Saturnalia expresses quite freely the belief that Horace sways between virtue and various frailties (1-45) and hence, as he is not firm in his frailties, he is worse than those whom he criticizes (verses 40-45).

The slave then comments on his master based on what he heard from the doorman-slave of the Stoic Crispinus, considering that Horace is not free and blissful but instead possessed by passions such as adultery and gluttony (46-115) - he is essentially one of Maecenas' slaves who hurries to meet him every time he calls him (32-35). ${ }^{15}$ However, Davus' remarks enrage Horace, who in turn threatens to send him to a Sabine farm if he does not stop accusing him, reminding him in this way that everything should be done in moderation:

14 Plaza 2006:113.

15 It seems that Crispinus is a recurring enemy for Horace and his Callimachean ideals throughout much of the first book of Satires. Whenever Crispinus appears in the liber sermonum, Horace mocks him for advocating or representing long-windedness and verbosity, e.g. at Satires 1.1.120-121 Horace promises to end his own speech, ne me Crispini scrinia lippi / compilasse putes — 'lest you assume that I've raided the bookcases of bleary-eyed Crispinus'; $c f$. Satires 1.4.13-21, where Horace derides Crispinus' challenge to see which of them can write more in a given time. So it stands to reason that whatever comes out of Crispinus' mouth into the ears of his janitor should be longwinded; now Davus has the cheek to pass this on to Horace on the occasion of the Saturnalia. See also Bond 1978:85-98. 
ocius hinc te ni rapis / accedes opera agro nona Sabino

if you don't take yourself off in a minute, you'll become the ninth slave on my Sabine farm (117-118).

In Satires 2.7, Davus is legally a slave, but in his actions he can be morally free and have self-control, unlike Horace, who is legally free but at the same time also a slave of his passions and a parasite of Maecenas. The poet, of course, allows Davus to accuse him falsely of immoral behaviour (e.g. gluttony) during the Saturnalia. In this way the comic element of the satire and its tendency to exaggerate are emphasized. In other words, the ideal notion of the relationship between master and slave is reversed, with the use of phraseology close to everyday speech (iam desine). Davus is one of Horace's minor personae who, like Damasippus in Satires 2.3, examines the poet from a Stoic perspective. The one who mocks becomes the subject of criticism in the satire, as he is presented as a puppet who is directly dependent on Maecenas. Davus even proclaims a sermo through which he personally disarms his criticism against Horace. It is reminiscent of the servus callidus of New Comedy and fabula palliata, who in this case uses his wit against and not in favour of his master. ${ }^{16}$ Even his name alludes to the slave who, in Terence's Andria, gets his master Pamphilus tangled up in an awkward situation instead of helping him in his love affair with Glycerium. Horace in turn allows Davus to acquire the role of the satirical poet whose listener is the creator himself, resulting in providing us with a diatribe $e^{17}$ in which the roles of master and servant, poet and listener are reversed. In Satires 2.7, Davus does not speak as a slave, but adopts the language of a master and belabours Horace within the context of the Decembri libertate, in a style appropriate to a satirist.

In general, the whole poem pertains to the spirit of the palliata and as in comedy there is a reversal of reality, the same applies in this case, within the spirit of the Saturnalia. In comedy, there are generally three types of slaves: 1) servi callidi, who are usually cunning and plot against others, such as Chrysalus in the Pseudolus of Plautus; 2) deceived slaves who are not architecti doli, on the contrary, they provoke the readers' laughter through the way they are deceived (Sceledrus in the Swaggering soldier); and 3) those who are different from Plato's typical model, such as Truculentus in the comedy The villager (Truculentus). ${ }^{18}$

As mentioned before, Davus belongs to the first category, that of a servus callidus. His relationship with Horace is reminicent of the relationship between

16 See Scullard 1987 on the relationship between the Saturnalia and Roman comedy: both manage to achieve an inversion of reality.

17 This term has often in the past been considered problematic. See also Muecke 1993:6, Godwin 2019:5-8 and Sharland 2010:16-22.

18 For a complete examination of the role of slaves in Plautus, $c f$. Stace 1968:64-77. 
master and slave in comedy, as both of them use humorous expressions familiar to readers from the fabula palliata. For instance, the use of the verb ausculto (hear) in verse 1 usually appears in Plautus:

Iamdudum ausculto et cupiens tibi dicere servos pauca reformido

I've been listening some time, and wishing to say a word to you, but as a slave I dare not to. ${ }^{19}$

Therefore, since the intention of Horace in Satire 2.7 is to deride the satirical poet, he puts forward a number of paradoxes for the satirical voice that in the context of humor and self-sarcasm serve the purposes of this particular genre. In other words, it appears that Davus is Horace's mask that acts as a means of self-criticism, in a satire which due to its ambivalent humour impedes us from understanding which information is true and which is mentioned in order to provoke laughter.

In both satires, Horace, as a satirical poet, essentially becomes the target of others' criticism. In the first one, the human foibles which were motifs of earlier satires (avarice, self-indulgence, lust) are presented here as phases of madness, and at the end of the poem the poet himself is harshly criticized by the slave. Satires 2.7 in turn is a Callimachean version of Satires 2.3; in both satires, Damasippus and Davus provoke the poet's wrath, although he does not refute their accusations. The satirist proves to be a victim of his passions, a stance appropriate to Epicurean philosophy, as opposed to the two men who examine him, as indicated earlier, through a Stoic, apathetic viewpoint. ${ }^{20}$

What also seems odd is the fact that the persona does not deny the accusations of unquenchable sexual desire, an element condemned by Epicurean philosophy, as well as of lust, greed and luxury, features that are directly associated with the poet in these two satires. Therefore, the subject of satire sacrifices the principles of Epicurus' philosophy of moderation and frugal living in order to be self-deprecating and provoke laughter - thus Horace abandons the respect for his persona to include witticism in his writing. ${ }^{21}$ After all, the two slaves include writing in their accusations against the poet:

adde poemata nunc, hoc est, oleum adde camino / quae siquis sanus fecit, sanus facis et tu

19 Muecke 1993:213. See also Bond 1978:1, who claims that Phaniscus in Plautus (Most. 859) displays timidity similar to that of Davus, one of the most common features of a slave who is devoted to his master.

20 In other words, Davus actually assails the poet's persona within the fictional world of his satires, as the poet in almost all the poems of this collection seems to use irony and mockery even against himself in order to achieve a comic result.

${ }^{21}$ Plaza 2006:211. 
Now throw in your verses - that is, throw oil on the fire / If any man ever wrote verses while he was sane, then you are sane in writing yours (Satires 2.3.321-322)

\section{Aut insanit homo aut versus facit}

The man's raving, or making verses (Satires 2.7.117).

This emphasises the literary aim behind these exaggerations, which is to highlight the basic principles of satire and also give prominence to the most striking defect of the persona, namely its excessive dependence on Maecenas. In other words, once more Horace appears as a puppet of his patron:

sapiens sibi qui im periosus / quem neque pauperies neque mors neque vincula terrent

Who then is free? The wise man, who is lord over himself, whom neither poverty nor death nor bonds frighten (verses 83-84).

Davus as a satirical persona takes advantage of the libertas granted him by the Saturnalia which is identified with the question of whether there may be candidness in a satire or not. This raises additional concerns for the genre, presenting the one who usually mocks as the target of criticism. Thus the inconsistencies included in Satires 2.7 in Horace's persona are characteristic of the satirical genre. The poet does not seem to be typically free, but as a satirist things could not be different for him. The sapiens, who is praised by Davus, could not write a good enough satire despite his perfection, while Davus, on the other hand, as a satirical persona is duplicitous and extravagant, so he does not meet the requirements of the wise. ${ }^{22}$ Nevertheless, this is the importance of humour in this satire, to expound the satirical paradoxes in such a humorous context that it seems ambivalent to decide what is true or deceptive while reading the poem. In this sense, Satires 2.7 becomes a miniature of this kind of satire; like Davus, the satirical poet also has freedom of expression and, at the same time, constraints (fines) himself. ${ }^{23} \mathrm{He}$ is never completely free, which is the reason why the temporary free Davus eventually becomes a slave again. ${ }^{24}$

Plaza 2006:220.

23 That Horace is serious in his comments at this stage is evident from the startling impact of the phrase comes atra (v. 115). As Bond 1978:96 claims, the idea of death and the fears that are connected with mortality seem inseparable from the figurative use of comes in the De rerum natura of Lucretius. Besides, Epicureans believed that death is inevitable, but needlessly, accompanied with the anxiety of what would proceed after death. This anxiety is always present and cannot be moderated by wine, nor does sleep provide any temporary redemption. At Lucr. 3.1046-1052, there is a juxtaposition of sleep and drink with curis that seems to anticipate Horace's vino ... somno in 
In fact, both Damasippus and Davus are two of Horace's personae who unveil the mask of the poet of the first book, while at the same time decry his ambition and enslavement to Maecenas. ${ }^{25}$ If we study them in conjunction with Ofellus in Satires 2.2, we will notice that the three men have similarities: they all suffer a reversal of fortune and a reduction of their social status. Therefore, they need satire, which is not a set of philosophical reflections, but a consolation for the defeated in life, which is expressed through philosophy in the second book. ${ }^{26}$ The latter in turn bolsters and at the same time comforts Ofellus, while it helps Damasippus regain his self-esteem and avoid committing suicide. Davus, on the other hand, acquires the status of a satirist as well as the privilege of free commentary, and offers on the occasion of the Saturnalia a diatribe in which the roles of master and slave, the satirist and the listener are reversed. He adopts the language which is appropriate to a master and as Horace's persona criticizes the poet, with a style that suits a satirical poet. ${ }^{27}$

It is still worth commenting that in Satires 2.7 Horace is likely to attribute to himself defects that he does not deserve, in his effort to announce through the comically inappropriateness of his satire his intentions to abandon the Roman literary genre which he inherited from Lucilius and which he reformed in his own way in his second book. After all, Satires 2.7 is his penultimate satire, so his intention might be to show us that the poet is tired of writing this kind of poetry and that he is ready for new writing endeavours. ${ }^{28}$

\section{Conclusion}

Overall, while the first book of Satires depicts the story of Horace's life and his rise from humble origins to a high position in the illustrious circle of Maecenas, in the second book the satirist of the first book is exposed. Like Ofellus in Satires 2.2, he lost his father's property due to the actions of the Triumvirate; like Damasippus he was saved when he turned to writing his satire; like Davus he exchanged his freedom and candidness for being in the service of his patron.

Satires 2.7.114 and the similar vini somnique benignus (satiated with wine and sleep) of 2.3.3. Furthermore, the spell woven by comes atra is reversed in the final verses, where Horace proves that in the real world facts are more important than theory, by threatening to exercise his rights as the actual master of Davus; as a result, Davus is presented again as a comic slave. The inversion of roles of master and slave which was sanctioned by the Saturnalia has officially come to an end.

24 Plaza 2006:221.

25 Gowers 2005:59.

26 Oliensis 1998:52.

27 Evans 1978:309.

28 Evans 1978:312. 
The first of these examples, Ofellus, is to the poet as Socrates is to Plato - the vehicle for his philosophical reflections. The second example, Damasippus, assails Horace, but also imitates him as satirist. The third example, Davus, ironically mocks Horace for being Maecenas' puppet, even while he is himself obviously Horace's puppet and mouthpiece.

Therefore, both Satires 2.3 and 2.7 contain elements of a diatribe and are placed in the context of the Saturnalian celebrations. Nevertheless, Satires 2.7 is considered more successful because it is shorter and focuses exclusively on Horace. In other words, the poet no longer needs to put on his satirical mask, because he is about to embark on a new writing venture, so he decides to address his satire against the persona he presented in his first book of Satires. ${ }^{29}$ Satires 2.7, after all, is considered to be the most complete of Horace's satires in that it refers to the satire itself. ${ }^{30}$ For this reason, I believe that the poet does not rebut the accusations against him that are uttered by his other two personae, Damasippus and Davus, as it is part of the satire to be comprised of a complex and ambiguous persona, a feature which without the portrait of the poet, achieved in Satires 2.3 and 2.7, would not be possible.

\section{BIBLIOGRAPHY}

Bernstein, M A 1987. O totiens servus: Saturnalia and servitude in Augustan Rome. CI 13:450-474.

Bond, R P 1978. A discussion of the various tensions in Horace, Satires 2.7. Prudentia 10:85-98.

-1987. The characterization of the interlocutors in Horace, Satires 2.3. Prudentia 19:1-21.

-1998. Horace on Damasippus on Stertinius ... Scholia 7:82-108.

Evans, H B 1978. Horace, Satires 2.7: Saturnalia and satire. CJ 73:307-312.

Godwin, J 2019. Selections from Horace Satires: An edition for intermediate students. London: Bloomsbury.

Gowers, E 2005. The restless companion: Horace, Satires 1 and 2. In Freudenburg, $\mathrm{K}$ (ed.), The Cambridge companion to Roman satire, 48-61. Cambridge: Cambridge University Press.

Muecke, Fr 1993. Horace, Satires II. Warminster: Aris \& Phillips.

Oliensis, E 1998. Horace and the rhetoric of authority. Cambridge: Cambridge University Press.

\footnotetext{
29 Oliensis 1998:56.

30 Evans 1978:312.
} 
Plaza, M 2006. The function of humor in Roman verse satire: Laughing and lying. Oxford/New York: Oxford University Press.

Rawson, E 1985. Intellectual life in the late Roman Republic. Baltimore: Johns Hopkins University Press.

Rudd, N 1966. The satires of Horace: A study. London: Cambridge University Press.

Schoder, R V 1944. Horace's satiric use of fable. CW 37:112-114.

Scullard, H H 1981. Festivals and ceremonies of the Roman Republic. Ithaca, NY: Cornell University Press.

Segal, E 1987. Roman laughter: The comedy of Plautus. New York/Oxford: Oxford University Press.

Shackleton Bailey, D R 1982. Profile of Horace. Cambridge, Mass.: Harvard University Press.

Sharland, S J 2005. Saturnalian satire: Proto-carnivalesque reversal and inversions in Horace Satire 2.7. AC 48:103-120.

2009. Soporific satire: Horace, Damasippus and Professor Snore (Stertinius) in Satires 2.3. AC 52:113-131.

2010. Horace in dialogue: Bakhtinian readings in the Satires. Bern: Peter Lang.

Stace, C 1968. The slaves of Plautus. G\&R 15:64-77.

Treggiari, S 1973. Cicero, Horace and mutual friends: Lamiae and Varrones Murenae. Phoenix 27:245-261.

Verboven, K 1997. Damasippus, the story of a businessman? In Deroux, C (ed.), Studies in Latin literature and Roman history VIII, 195-217. Brussels: Peeters. 